\title{
Purification and characterization of cytosolic and cell wall $\beta$-galactosidases from Vigna unguiculata stems
}

\section{Fabrício Bonfim Sudério, ${ }^{1,2}$, Gislainy Karla da Costa Barbosa ${ }^{1}$, Enéas Gomes-Filho' and Joaquim Enéas-Filho ${ }^{1 *}$}

${ }^{1}$ Laboratório de Fisiologia Vegetal, Departamento de Bioquímica e Biologia Molecular, CC/UFC, CP 6039, 60.455970, Fortaleza, CE, Brazil.

${ }^{2}$ Universidade Estadual do Ceará, Faculdade de Educação de Crateús, Rua Dr. José Furtado S/N - Prédio do CAIC, Bairro Cidade Nova - Crateús - CE, CEP 63.700-000, Brasil.

*Corresponding author. tel.: (+55) 853366 9827; fax (+55) 853366 9829; e-mail: joaquime@ufc.br Received: 31 March 2010; Accepted: 05 November 2010.

\begin{abstract}
Three $\beta$-galactosidase isoforms, $\beta$-gal I and $\beta$-gal II (cytosolic) and $\beta$-gal III (cell wall-associated), were isolated from stems of Vigna unguiculata (L.) Walp. cv. Pitiúba seedlings. Purification consisted of ammonia sulfate fractionation followed by chromatography in DEAE-Sephadex and Lactosyl-Sepharose columns. The two cytosolic isoforms showed the same chromatography pattern, which differed from that of $\beta$-gal III. Electrophoresis revealed a single band of protein for $\beta$-gal II and $\beta$-gal III which also expressed $\beta$-galactosidase activity in gel. The apparent molecular mass of the $\beta$-gal I, II and III was 89, 146 and $124 \mathrm{kDa}$, respectively. The three isoforms revealed the same optimal $\mathrm{pH}(4.0)$ and the same optimal assay temperature $\left(55^{\circ} \mathrm{C}\right)$ for enzyme activity. The three isoforms were stable at temperatures up to $50^{\circ} \mathrm{C}$, and incubation with glucose and galactose expanded their thermal stability as well as inhibited their activities. Galactose was the most effective in promoting these effects and $\beta$-gal I and II were competitively inhibited by this sugar. Kinetic analysis using $\beta$-PNPG as substrate, revealed KM of 1.69, 1.76 and 1.43 for $\beta$-gal I, $\beta$-gal II and $\beta$-gal III, respectively. The $\beta$-gal I was able to hydrolyze all synthetic substrates tested, whereas $\beta$-gal II exhibited only $\beta$-fucosidase and $\alpha$-arabinosidase activities, and $\beta$-gal III was limited to the $\alpha$-galactosidase, $\beta$-fucosidase and $\alpha$-arabinosidase activities. These results are consistent with three distinct $\beta$-galactosidases exhibiting quite similar kinetic features, but endowed with different functional specificities probably related to their specific roles in the plant cell physiology.
\end{abstract}

Key words: enzymatic kinetics, cowpea, optimal pH, enzyme purification, thermal stability, thermal inactivation

\section{INTRODUCTION}

The degradation of cell wall polysaccharides depends on action by various enzymes, which were classified by Fry (2004) in exopolysaccharides, endopolysaccharides and other hydrolases. After synthesis and deposition of wall polysaccharides, these enzymes participate in the degradation of different cell wall polysaccharides and may result in changes in their structure and composition. The polysaccharides thus act in the regulation of cell wall alterations and expansions.
However, no information has been reported on the exact cell location of these enzymes (Minic and Jouanin, 2006).

Glycoside hydrolases form an ample group of enzymes that hydrolyze glycoside bonds between two or more carbohydrates or between one carbohydrate and another type of macro molecule (Minic and Jouanin, 2006; PérezAlmeida and Carpita, 2006). Various studies report that $\beta$-galactosidases (EC 3.2.1.23) act on cell wall components and can promote their loosening and the consequent 
elongating of the cell (Minic and Jouanin, 2006; PérezAlmeida and Carpita, 2006). These enzymes act as lactases and transglycosylases (Mathews, 2005) and catalyze the enzymatic hydrolysis between the carbohydrates glycosidic bonds (Pérez-Almeida and Carpita, 2006).

For understanding the physiological roles of new $\beta$-galactosidases, the proteins need to be purified previously in order to perform studies on their physical and catalytic properties. Besides the purification and characterization studies of $\beta$-galactosidases of vegetative organs (Konno and Tsumuki, 1993; Sawicka and Kacperska, 1995), several studies have also been conducted on the characterization of $\beta$-galactosidases isolated from storage organs (EnéasFilho et al., 2000; Balasubraniam et al., 2005; Alcântara et al., 2006). The differences observed among these $\beta$-galactosidases should reflect differences between cultivars and species, different organs, different locations in the cell, possible modifications during plant development and different conditions to which the plants were submitted. Characterize the protein molecular mass, the optimal pH and temperature for catalysis, the thermo stability in the presence of sugars, effects of some sugars on enzymatic activity, kinetic analysis including determination of the enzyme affinity and specificity to different substrates. The $\beta$-galactosidases act on mobilization of cell wall constituents during plant germination and growth. According to Chilaka et al. (2002), $\beta$-galactosidase stabilizes against thermo inactivation in the presence of glucose and galactose, suggesting that the thermo inactivation route involves changes in the active enzyme site, so that exposure of such to high temperatures may not necessarily deactivate it due to the protection offered by these sugars, making it more resistant to high temperatures (Chilaka et al., 2002). On the other hand, some sugars can also bind to active sites or any other enzyme region, acting as competitive, uncompetitive or non-competitive inhibitors, reducing the product formation rate in the reaction (Nelson and Cox, 2000).

Cowpea stems were object of this study due to the lack of information on $\beta$-galactosidases from this kind of plant tissue. Towards this end it was purified and characterized $\beta$-galactosidases derived from the cytosol and cell walls isolated from cowpea seedlings hypocotyls. A comparative analysis was carried out among the cytosolic $\beta$-galactosidases and those from cell walls in order to provide information about the biochemical identity of these enzymes.

\section{MATERIALS AND METHODS}

Vegetal material, germination and collection conditions: Cowpea [Vigna unguiculata (L.) Walp.], cultivar Pitiúba seeds were used. Seeds treated with sodium hypochlorite for five minutes (Gomes-Filho and Prisco, 1978) were sowed in distilled water in sheets of filter paper, for a 12 h photoperiod, irradiance of $16 \mu \mathrm{mol} \mathrm{m} \mathrm{m}^{-2} \mathrm{~s}^{-1}$, temperature of $25 \pm 2^{\circ} \mathrm{C}$ and relative humidity near $100 \%$. After sowing, the seedlings were selected and collected in development stage VIII (radicle longer than $5 \mathrm{~cm}$, cotyledons outside the paper, straight hypocotyl and open, cotyledonal leaves), according to Sousa et al. (2004). After collection, the stems were lyophilized, macerated and stored at $10^{\circ} \mathrm{C}$.

Extraction and purification of cytosol and cell wall $\beta$-galactosidases: Lyophilized stems were macerated in a sodium citrate buffer $25 \mathrm{mM}$ - potassium phosphate $50 \mathrm{mM}$, pH 5.5 (Mcllvaine buffer) with polyvinylpyrrolidone (PVP) $0.1 \%$, at a proportion of $1: 50(\mathrm{~m} / \mathrm{v})$, for one hour in an ice bath. The homogenate was centrifuged at $16,000 \mathrm{~g}$ for 30 minutes, at $4^{\circ} \mathrm{C}$. The supernatant (containing the cytosolic proteins) was precipitated with ammonia sulfate $20-80 \%$, centrifuged and dialyzed against deionized water for 24 hours, at $4^{\circ} \mathrm{C}$, obtaining a cytosolic protein fraction $\left(\mathrm{F}_{20-80}\right)$ (Enéas-Filho et al., 1995). The precipitate was resuspended and washed with a sodium phosphate buffer $10 \mathrm{mM}, \mathrm{pH} 7.0$, at $10^{\circ} \mathrm{C}$. The residue was then washed with acetone at $-20^{\circ} \mathrm{C}$, and then washed with the same buffer. The residue was resuspended in a sodium citrate buffer $10 \mathrm{mM} /$ sodium phosphate $10 \mathrm{mM}$, pH 5.5, with $3 \mathrm{M} \mathrm{NaCl}$ and PVP $0.1 \%(\mathrm{~m} / \mathrm{v})$, at $4^{\circ} \mathrm{C}$, for 24 hours, under agitation. After centrifugation at $16,000 \mathrm{xg}$, for 15 minutes, the supernatant was filtered, dialyzed against a sodium citrate buffer $10 \mathrm{mM} /$ sodium phosphate $10 \mathrm{mM}$, pH 5.5 , for 24 hours, at $4^{\circ} \mathrm{C}$ and centrifuged at $16,000 \times$ g, for 15 minutes. The supernatant was precipitated with ammonia sulfate at a saturation range of $40-100 \%$, centrifuged, resuspended and dialyzed against deionized water for 24 hours, at $4^{\circ} \mathrm{C}$, obtaining a $\left(\mathrm{F}_{40-100}\right)$ protein fraction ionically cell wall-bound (Seara et al., 1988).

Contamination of the cowpea hypocotyls extracellular fluid by cytoplasmic proteins was prevented by using the same procedure adopted by Gómez et al. (1995), which obtained extracellular fluid with only 1.5 and $1.4 \%$ of contamination with cytosolic and vacuolar proteins, respectively. Cell wall preparation purity was tested by accessing marker enzymes, 
the cytosolic glucose-6-phosphate and the vacuolar acid phosphatase dehydrogenase. Glucose-6-phosphate dehydrogenase activity was determined according to Molina et al. (2003) and vacuolar acid phosphatase activity was determined according to the Granjeiro et al. (2003) method. In general, each ion exchange chromatography (DEAE Sephadex A-50) received $150,000 \mathrm{UA} \times \mathrm{h}^{-1}$ of the $20-80 \%$ fraction $\left(\mathrm{F}_{20}\right.$ ${ }_{80}$ - cytosolic proteins), lyophilized and dissolved in $5.0 \mathrm{~mL}$ of a Tris- $\mathrm{HCl} 25 \mathrm{mM}$ buffer, $\mathrm{pH}$ 7.2, with chromatography performed at a flow of $31.5 \mathrm{~mL} \times \mathrm{h}^{-1}$, at $4^{\circ} \mathrm{C}$. Elution was conducted with a saline gradient $(0.2-1.0 \mathrm{M} \mathrm{NaCl}$, in a Tris$\mathrm{HCl} 25 \mathrm{mM} \mathrm{pH} 7.2$ buffer; $100 \mathrm{~mL}$ ) (Enéas-Filho et al., 2000). $\beta$-galactosidase activity peaks were gathered and dialyzed against deionized water for 24 hours, at $4^{\circ} \mathrm{C}$, concentrated separately by partial lyophilization and applied to an affinity column (Lactosyl-Sepharose). The 40-100\% lyophilized fraction $\left(\mathrm{F}_{40-100}\right.$ - proteins ionically cell wall-bound) was applied directly to the affinity column at a flow of $36.0 \mathrm{~mL} \times \mathrm{h}$ ${ }^{1}$ at $4^{\circ} \mathrm{C}$. Elution was conducted with the equilibrium buffer, containing lactose $100 \mathrm{mM}$ and $\mathrm{NaCl} 0.5 \mathrm{M}$. Fractions rich in $\beta$-galactosidase activity were united, dialyzed against deionized water for 24 hours, at $4^{\circ} \mathrm{C}$, and stored at $-20^{\circ} \mathrm{C}$ (Enéas-Filho et al., 2000).

Determinations of $\beta$-galactosidase activity and protein content: $\beta$-galactosidase activity was determined according to Kanfer et al. (1973), with modifications. Reaction mixture was composed of $0.5 \mathrm{~mL}$ of extract and the synthetic $3 \mathrm{mM}$ p-nitrophenyl- $\beta$-D-galactopyranoside substrate ( $\beta$-PNPG) in a Mcllvaine pH 4.0 buffer. After 15 minutes at $55^{\circ} \mathrm{C}$ in a double boiler, the reaction was interrupted by adding $1.5 \mathrm{~mL}$ of 0.1 $\mathrm{M}$ sodium carbonate. Enzymatic activity was determined by the quantity of product formed, measuring absorbance in $400 \mathrm{~nm}\left(\mathrm{~A}_{400}\right)$, where one UA corresponds to one $0.01 \Delta \mathrm{A}_{400}$. The determination of protein concentrations was performed according to Bradford (1976) using bovine serum albumin as standard.

\section{Electrophoresis in polyacrylamide gel (PAGE-native)} in acid conditions: Electrophoresis was conducted in native conditions (PAGE-native) and at acidic $\mathrm{pH}$ according to Goldenberg (1997), with modifications. Purified $\beta$-galactosidases were equilibrated with a potassium acetate buffer $1 \mathrm{M}$, pH 6.8, containing glycerol (50\%) and basic fuchsine $(0.005 \%)$. Purified enzymes $(30 \mu \mathrm{L})$ were applied in duplicate, separately, in the wells and the electrophoretic pattern developed in $0.14 \mathrm{M}$ acetate buffer - $0.35 \mathrm{M} \beta$-alanine, $\mathrm{pH} 4.3$, at a current of $30 \mathrm{~mA}$ in the direction of the cathode for approximately five hours. In the end, the polyacrylamide gel was divided in half. One half was used for the specific staining of the $\beta$-galactosidase activity (Simos and Georgatsos, 1988). For this, the synthetic substrate 6-bromo-2-naphthyl- $\beta$-Dgalactopyranoside $(4.0 \mathrm{mM})$ was used. The other half was used to stain proteins with silver nitrate according to Blum et al. (1987).

Characterization and properties of $\beta$-gal I, $\beta$-gal II and $\beta$-gal III: Molecular mass was determined in G-150 Sephadex gel filtration chromatography (Biswas, 1987) at a flow of 18 $\mathrm{mL} \times \mathrm{h}^{-1}$, which was equilibrated with $25 \mathrm{mM}$ Tris- $\mathrm{HCl}, \mathrm{pH} 7.2$ buffer. Enzymatic activities were studied in a $\mathrm{pH}$ range that varied between 2.5 and 6.5 , at 0.5 intervals. The activity assay for determining the optimal temperature of enzymes was run at temperatures of $30,40,50,55,60,70$ and $80^{\circ} \mathrm{C}$. In order to determine $\beta$-galactosidase thermal stability, $0.5 \mathrm{~mL}$ aliquots of the enzymatic solution were incubated for 10 minutes at different temperatures $\left(30,40,50,60,70\right.$ and $\left.80^{\circ} \mathrm{C}\right)$, followed by cooling in an ice bath and subsequent determination of enzymatic activity in standard assay conditions. The thermal inactivation of enzymes was verified through the pre-incubation of $0.5 \mathrm{~mL}$ aliquots at $60^{\circ} \mathrm{C}$ for $20,40,60$ and $80 \mathrm{~min}$, in the absence and presence of $50 \mathrm{mM}$ galactose or glucose. After incubation, the aliquots were placed in ice baths and then the enzymatic activity was determined in standard conditions and expressed in percentages of control (control 1- sample without thermal treatment and in the absence of sugars; control 2 - sample without thermal treatment in the presence of $50 \mathrm{mM}$ galactose; control 3 - sample without thermal treatment in the presence of $50 \mathrm{mM}$ glucose). In order to analyze the effect of some sugars in $\beta$-galactosidase activity, assays were conducted in standard conditions, in the absence (control) and presence of lactose, galactose, arabinose and fucose sugars (all at concentrations of $50 \mathrm{mM}$ ).

Kinetic analysis of each purified $\beta$-galactosidase was carried out at increasing concentrations of $\beta$-PNPG (1.0, 1.5, 2.0, 2.5, 3.0, 3.5, 4.0, 4.5 and $5.0 \mathrm{mM}$ ), used as standard substrate, $K_{M}$ and $V_{\text {Max }}$ were determined by performing the double reciprocal Lineweaver-Burk plot. An inhibitory kinetic was analyzed for the $\beta$-galactosidases as a function of increasing concentrations of galactose $(2.5,10,20$ and $30 \mathrm{mM})$ and of the $\beta$-PNPG substrate $(2.0,2.5,3.5,5.0$ and $10.0 \mathrm{mM})$. The 
specificity of each purified $\beta$-galactosidase was estimated by their capacity to hydrolyze the synthetic substrates: $p$-nitrophenyl $\beta$-D-xylopyranoside, $\quad \mathrm{p}$-nitrophenyl $\quad \beta$-D-fucopyranoside, $p$-nitrophenyl $\quad \beta$-D-glucopyranoside, $\quad p$-nitrophenyl $\alpha$-Larabinopyranoside, $\quad p$-nitrophenyl $\alpha$-D-mannopyranoside, p-nitrophenyl $\alpha$-D-galactopyranoside and $p$-nitrophenyl $\alpha$-Lfucopyranoside (all at concentrations of $3 \mathrm{mM}$ ). Enzymatic activity values were expressed in percentages of control ( $\beta$-Dgalactosidase activity), using the $\beta$-PNPG substrate.

\section{RESULTS}

Fractions containing cytosolic proteins presented almost all $\beta$-galactosidase activity in the $20-80 \%$ range, while fractions containing cell wall proteins presented most of their activity in the $40-100 \%$ range (Table 1). The $F_{20-80}$ fraction for cytosolic protein presented a $98.7 \%$ recovery in $\beta$-galactosidase activity and 1.8 times purification, while $F_{40-100}$ for cell wall proteins was obtained with a 40.1 recovery of $\beta$-galactosidase activity and purification of 1.1 times (Table 1).

The DEAE-Sephadex A-50 column chromatography profile for $F_{20-80}$ of cytosolic proteins revealed the existence of two protein peaks $\left(A_{280}\right)$, one non-retained (DS I) and the other adsorbed to DEAE-Sephadex (DS II) (Figure 1A). Both the DS I and the DS II peaks presented $\beta$-galactosidase activity. DS I and DS II protein fractions showed purification of 10.1 and 1.5 times, respectively (Table 1).

DS I and DS || fractions were applied on a LactosylSepharose affinity column. Application of DS I in the affinity column resulted in a big non-retained protein peak $\left(A_{280}\right)$ in the column, with residual $\beta$-galactosidase activity that was not used for subsequent analyses. On the other hand, the peak that was retained, called $\beta$-gal I, presented almost all $\beta$-galactosidase activity (Figure 1B) and purification of 133.5 times (Table 1). When DS II was applied to affinity chromatography, the chromatography profile also resulted in two peaks at $A_{280}$, one non-retained, very evident, but with very low $\beta$-galactosidase activity that was not used in the analyses, and the other retained, with expressive $\beta$-galactosidase activity, which was called $\beta$-gal II (Figure 1C) and a purification of 21.4 times (Table 1).

The chromatography profile of cell wall proteins for $F_{40}$ 100 derived from Lactosyl-Sepharose column revealed the existence of a non-retained protein peak $\left(A_{280}\right)$, with residual $\beta$-galactosidase activity that was not used in subsequent analyses, and the other, retained, with a considerable percentage of $\beta$-galactosidase activity, which was called $\beta$-gal III (Figure 1D) and which presented purification of 52.3 times (Table 1).

Electrophoretic analysis $\beta$-galactosidases isolated revealed that $\beta$-gal II and $\beta$-gal III presented a single protein band that corresponded to the same band with $\beta$-galactosidase activity (Figure 2). However, due to little quantity of protein and enzymatic activity of $\beta$-gal I, the revelation of protein with silver and the determination of enzymatic activity were not effective and identification was thus not possible.

The Sephadex G-150 column chromatography profile for the three $\beta$-galactosidase isoforms revealed apparent molecular masses of 89,146 and $124 \mathrm{kDa}$ for $\beta$-gal I, $\beta$-gal II and $\beta$-gal III, respectively (Figure 3 ).

Table 1. Purification of cytosolic and cell wall $\beta$-galactosidases of cowpea seedling stems [Vigna unguiculata (L.) Walp.] cv. Pitiúba.

\begin{tabular}{|c|c|c|c|c|c|}
\hline \multicolumn{6}{|c|}{ Cytosolic $\beta$-galactosidases } \\
\hline $\begin{array}{l}\text { Purification } \\
\text { step }\end{array}$ & $\begin{array}{l}\text { Activity } \\
\left(\text { UA. } h^{-1}\right)\end{array}$ & $\begin{array}{l}\text { Protein } \\
(\mathrm{mg})\end{array}$ & $\begin{array}{c}\text { Specific Activity } \\
\left(\text { (UA.mgP }^{-1} \cdot h^{-1}\right)\end{array}$ & $\begin{array}{l}\text { Recovery } \\
(\%)\end{array}$ & $\begin{array}{l}\text { Purification factor } \\
\text { (fold) }\end{array}$ \\
\hline Crude Extract & $3,003,000$ & 194.4 & 15,448 & 100 & 1 \\
\hline$F_{20-80}$ & $2,966,080$ & 106.4 & 27,877 & 98.8 & 1.8 \\
\hline DS-I & $1,174,333$ & 7.5 & 156,578 & 39.1 & 10.1 \\
\hline DS-II & 744,785 & 31.5 & 23,644 & 24.8 & 1.5 \\
\hline$\beta$-gal I & 453,696 & 0.2 & 2062,255 & 15.1 & 133,5 \\
\hline$\beta$-gal II & 245,180 & 0.7 & 331,324 & 8.2 & 21,4 \\
\hline \multicolumn{6}{|c|}{ Cell wall $\beta$-galactosidase } \\
\hline $\begin{array}{l}\text { Purification } \\
\text { step }\end{array}$ & $\begin{array}{l}\text { Activity } \\
(\text { UA.h. }\end{array}$ & $\begin{array}{c}\text { Protein } \\
(\mathrm{mg})\end{array}$ & $\begin{array}{l}\text { Specific Activity } \\
\left(\text { (UA.mgP } \mathrm{P}^{-1} \cdot \mathrm{h}^{-1}\right)\end{array}$ & $\begin{array}{c}\text { Recovery } \\
(\%)\end{array}$ & $\begin{array}{l}\text { Purification factor } \\
\text { (fold) }\end{array}$ \\
\hline Crude Extract & 209,040 & 11.04 & 18,935 & 100 & 1 \\
\hline$F_{40-100}$ & 84,014 & 3.87 & 21,709 & 40.2 & 1.1 \\
\hline$\beta$-gal III & 59,418 & 0.06 & 990,300 & 28.4 & 52.3 \\
\hline
\end{tabular}




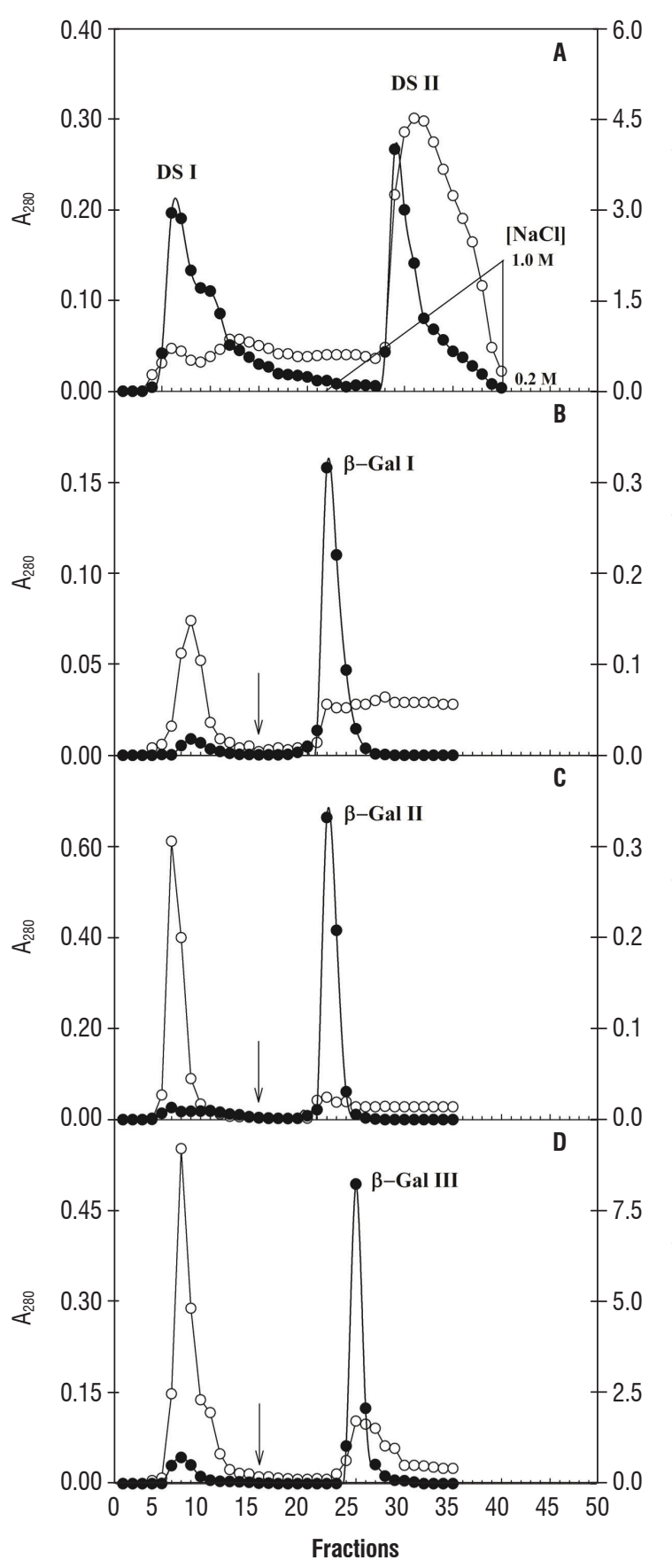

Figure 1. Purification of cytosolic (A, B and $C$ ) and cell wall (D) $\beta$-galactosidases of cowpea seedling stems [Vigna unguiculata (L.) Walp.] A. DEAE-Sephadex chromatography of the fraction rich in $\beta$-galactosidase activity $\left(F_{20-80}\right)$. B. and C. Lactosyl-Sepharose affinity chromatography of non-retained (DS I) and retained (DS II) DEAESephadex peaks of cytosolic $\beta$-galactosidases, respectively. D. LactosylSepharose affinity chromatography of the fraction rich in $\beta$-galactosidase activity $\left(F_{40-100}\right)$. Protein $\left(A_{280} \circ\right)$ and $\beta$-galactosidase activity $\left(\Delta A_{400}\right.$ $15 \mathrm{~min}^{-1} \longrightarrow$. The arrow indicates the beginning of the use of the elution buffer containing $100 \mathrm{mM}$ lactose and $0.5 \mathrm{M} \mathrm{NaCl}$.
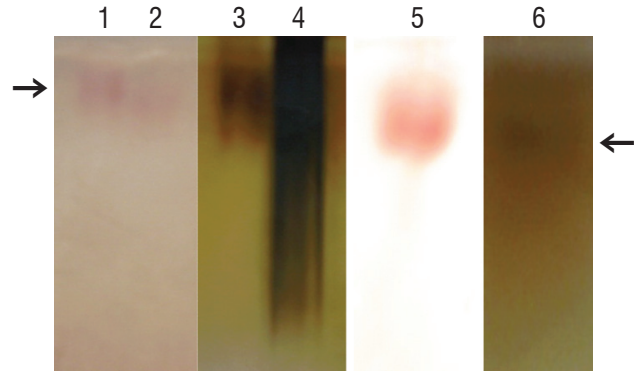

Figure 2. Electrophoresis in polyacrylamide gel in native conditions (gradient $5-15 \%$ ), in acidic $\mathrm{pH}$. The bands correspond to the $\beta$-galactosidases of cowpea seedling stems [Vigna unguiculata (L.) Walp.] cv. Pitiúba. 1. $\beta$-gal II (cytosolic) - $10 \mu \mathrm{g}$ of protein; 2. $\beta$-gal II (cytosolic) - $5 \mu \mathrm{g}$ of protein; 3. $\beta$-gal II (cytosolic) - $1.25 \mu \mathrm{g}$ of protein; 4. $\beta$-gal II (cytosolic) $-2.5 \mu \mathrm{g}$ of protein; 5 . $\beta$-gal III (cell wall) - $10 \mu \mathrm{g}$ of protein; $\mathbf{6}$. $\beta$-gal III (cell wall) $-1.25 \mu \mathrm{g}$ of protein. The lanes 1 , 2 ( $\beta$-gal II) and 5 ( $\beta$-gal III) represents the specific staining of $\beta$-galactosidase activity. The lanes 3, 4 ( $\beta$-gal II) and 6 ( $\beta$-gal III) represents the protein staining.

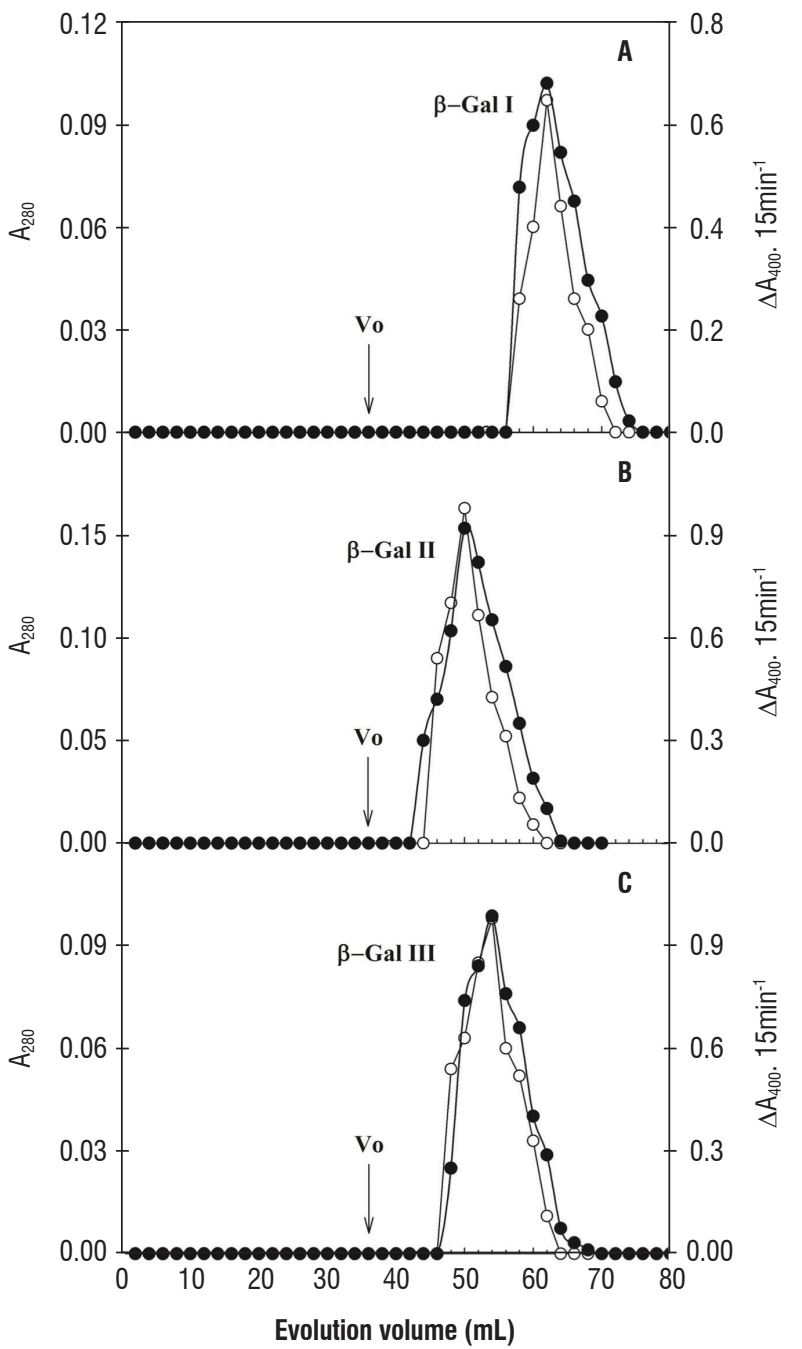

Figure 3. Sephadex G-150 elution profile for determining the molecular mass of $\beta$-gal I, $\beta$-gal II and $\beta$-gal III of cowpea seedling stems [Vigna unguiculata $\left(\mathrm{L}\right.$.) Walp.] cv. Pitiúba. Protein $\left(\mathrm{A}_{280} \circ\right)$ and $\beta$-galactosidase activity $\left(\Delta \mathrm{A}_{400} \cdot 15 \mathrm{~min}^{-1} \bullet\right)$. 
Enzymatic activities of cytosolic ( $\beta$-gal I and $\beta$-gal II) and cell wall ( $\beta$-gal III) $\beta$-galactosidases as a function of $\mathrm{pH}$ in the reaction medium can be observed in figure 4A. In all samples analyzed, there was an increase in enzymatic activity starting at $\mathrm{pH} 2.5$ until reaching maximum activity at $\mathrm{pH} 4.0$, with a progressive decrease until pH 6.5.

Optimal assay temperature for $\beta$-gal I, $\beta$-gal II and $\beta$-gal III enzymes was $55^{\circ} \mathrm{C}$, and in all there was very little difference in activity between 55 and $60^{\circ} \mathrm{C}$ and a considerable drop in activity after $60^{\circ} \mathrm{C}$ (Figure 4B). However, in $\beta$-gal I and $\beta$-gal II there was considerable difference in activity between 50 and $55^{\circ} \mathrm{C}$, contrary to $\beta$-gal III, where there is very little difference in activity between these temperatures (Figure 4B).

In the thermal stability study of $\beta$-gal I, II and III enzymes (Figure 4C), $\beta$-gal I presented a reduction in activity when incubated at a temperature of $40^{\circ} \mathrm{C}$. At $60^{\circ} \mathrm{C}$, they all presented a pronounced drop until complete inactivation at $70^{\circ} \mathrm{C}$. In general, thermal inactivation curves (pre-incubation of enzymes at $60^{\circ} \mathrm{C}$ ) as a function of time $(20,40,60$ and 80 minutes) for $\beta$-gal I, II and III (Figure 5) showed that in the absence of any sugar (control) the curves were biphasic, with an initial rapid phase, with great loss of activity, and a second phase that was slower. Pre-incubation of $\beta$-gal III at $60^{\circ} \mathrm{C}$, for 40 minutes, resulted in the almost complete inactivation of enzyme activity. However, for $\beta$-gal I and II enzymes, this only occurred with 80 minutes of preincubation. Figure 5 also shows the thermal inactivation study of $\beta$-gal I, II and III in the presence of glucose and galactose. Glucose and galactose increased the thermal stability of enzymes, where activity loss was less in the presence of galactose than in the presence of glucose. Of all those sugars tested for their effects on $\beta$-gal I, II and III activities (Table 2), in the presence of $\beta$-PNPG, the higher inhibition was caused by galactose, followed by lactose and fucose. In general, arabinose had the least effect on $\beta$-gal I, II and III activity.
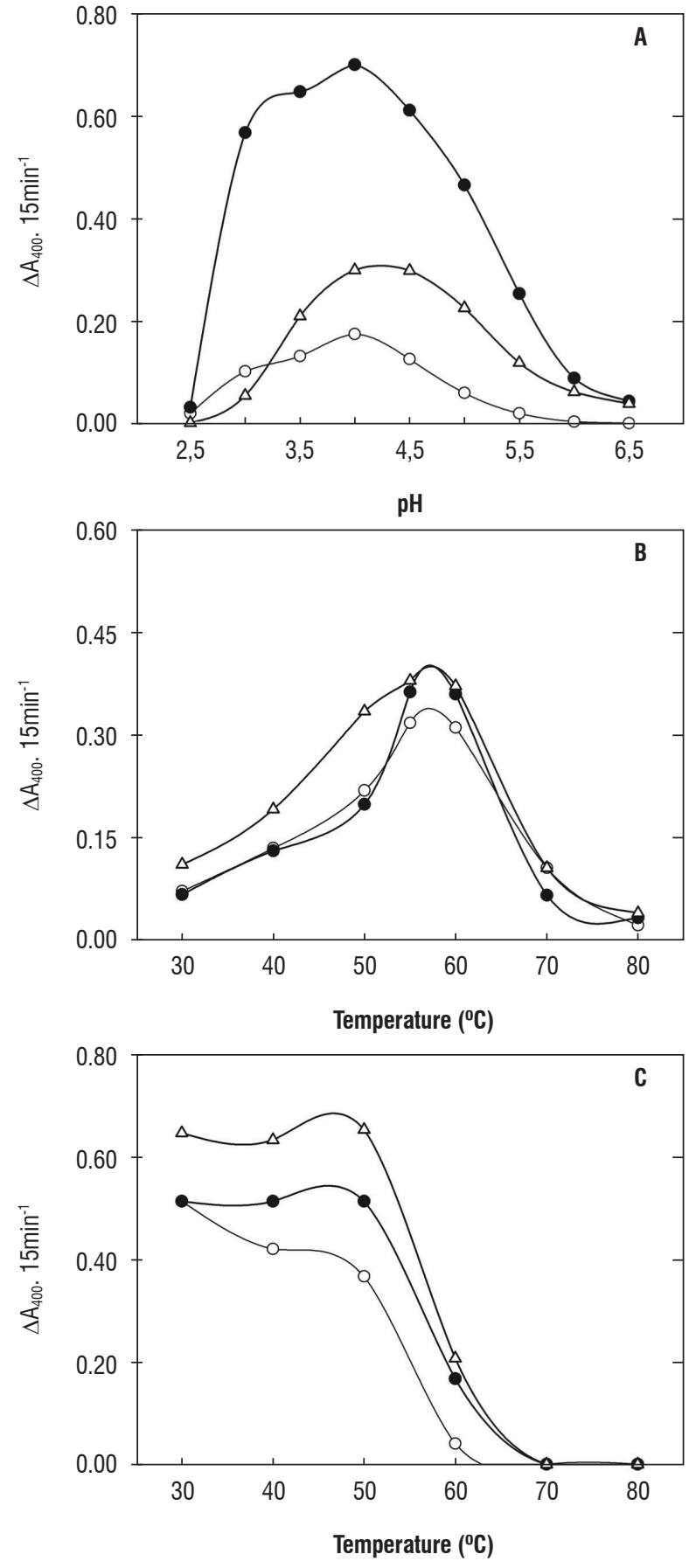

Figure 4. A. $\beta$-galactosidase activity as a function of $\mathrm{pH}$; $\mathbf{B}$. Effect of assay medium temperature on $\beta$-galactosidase activity; $\mathbf{C}$. $\beta$-galactosidase activity as a function of pre-incubation temperature. Cytosolic $\beta$-galactosidases ( $\beta$-Gal I, $\multimap$ and $\beta$-Gal II, ๑) and those present in the cell wall ( $\beta$-Gal III, $\Delta-\Delta$ ) of cowpea seedling stems [Vigna unguiculata (L.) Walp.] cv. Pitiúba. 


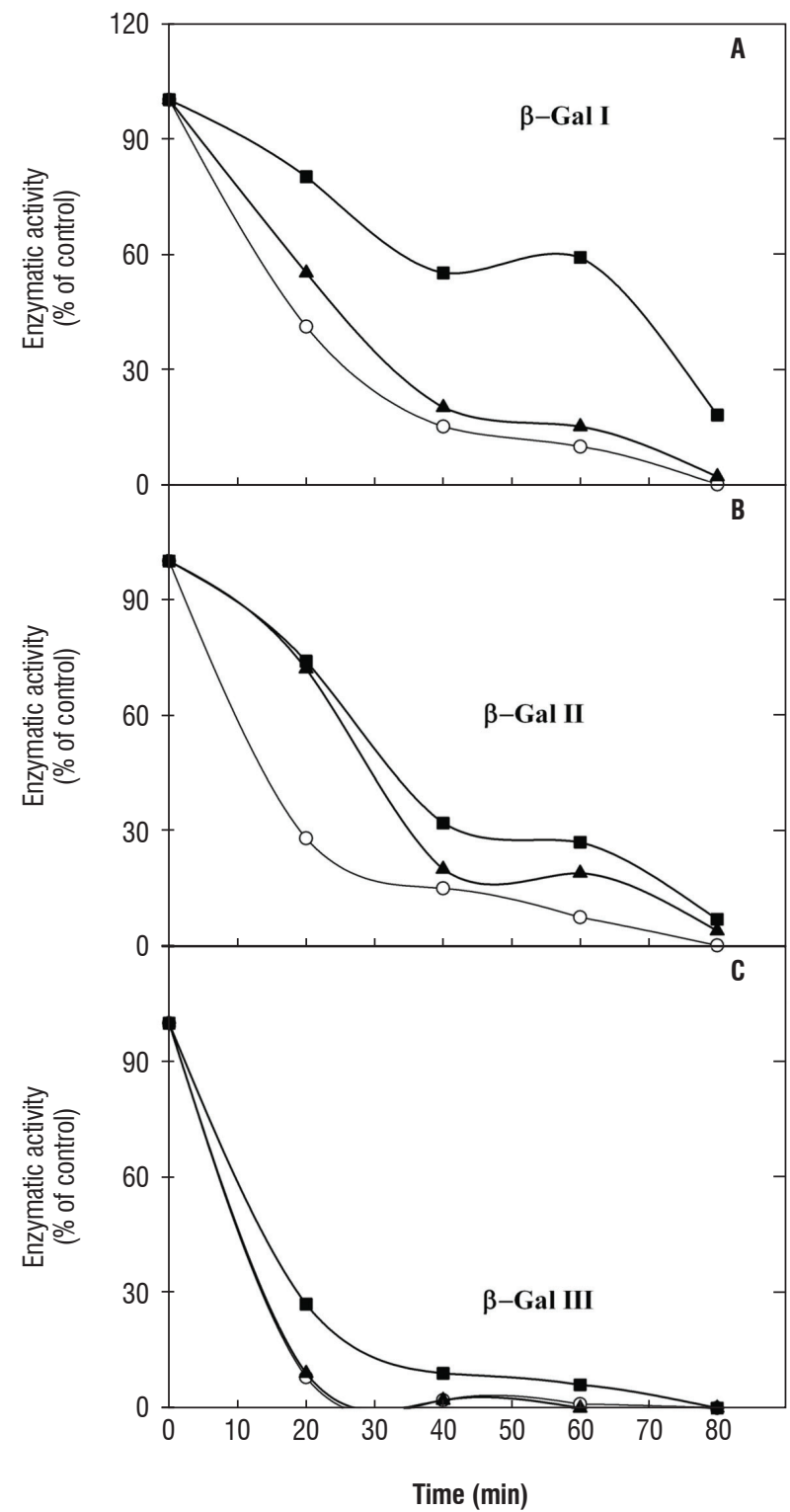

Figure 5. Thermal inactivation of $\beta$-gal I, $\beta$-gal II and $\beta$-gal III of cowpea seedling stems [Vigna unguiculata (L.) Walp.] cv. Pitiúba, in the absence $(\circ)$ and presence of $50 \mathrm{mM}$ glucose $(\mathbf{\Lambda}-\mathbf{\Lambda})$ and $50 \mathrm{mM}$ galactose $(\longrightarrow)$.
Table 2. Effect of sugars on the $\beta$-gal I, $\beta$-gal II and $\beta$-gal III activities of cowpea seedling stems [Vigna unguiculata (L.) Walp.] cv. Pitiúba.

[ $\beta$-galactosidase activity (UA.h-1)] / [\% of control ( $\beta$-PNPG)]

\begin{tabular}{cccc}
\hline Treatment & $\beta$-gal I & $\beta$-gal II & $\beta$-gal III \\
\hline Control & $204.8(100 \%)$ & $2,297.6(100 \%)$ & $992.0(100 \%)$ \\
Lactose (50 mM) & $131.2(64.1 \%)$ & $1,675.2(72.9 \%)$ & $742.4(74.8 \%)$ \\
Galactose (50 mM) & $54.4(26.6 \%)$ & $656.0(28.6 \%)$ & $163.2(16.5 \%)$ \\
Arabinose (50 mM) & $172.8(84.4 \%)$ & $1,795.2(78.1 \%)$ & $902.4(91 \%)$ \\
Fucose (50 mM) & $103.2(50.4 \%)$ & $1,817.9(79.1 \%)$ & $860.8(86.8 \%)$ \\
\hline
\end{tabular}

In the hydrolysis of the $\beta$-PNPG substrate, catalyzed by $\beta$-gal I, II and III, a type of Michaelis-Menten kinetics can be observed (Figure 6). Numerical values for $K_{M}$ and $V_{\text {Max }}$ for $\beta$-gal I, II and III were $1.69 \mathrm{mM}$ and $0.29 \mu \mathrm{mol} . \mathrm{mg}^{-1}$. prot. ${ }^{-1}$ of $1.76 \mathrm{mM}$ and $0.96 \mu \mathrm{mol}^{\mathrm{mg}} \mathrm{mg}^{-1}$. prot. $^{-1}$ and $1.43 \mathrm{mM}$ and 0.47 $\mu \mathrm{mol} . \mathrm{mg}^{-1}$. prot. ${ }^{-1}$, respectively.

The study of $\beta$-gal I, $\beta$-gal II and $\beta$-gal III activities, as to their capacities to hydrolyze different substrates, is shown in Table 3. $\beta$-gal I presented activity for all tested synthetic substrates, where $\beta$-fucosidase activity was the most evident, representing $94 \%$ of control activity ( $\beta$-galactosidase activity). Different results were observed in relation to $\beta$-gal II, which only presented $\beta$-fucosidase and $\alpha$-arabinosidase activities, which represented 21 and $10 \%$ of control activity, respectively. Of all tested substrates, the one $\beta$-gal III hydrolyzed at greater proportions was PNP$\alpha$-D-glucopyranoside, which represented $32 \%$ of control activity ( $\beta$-PNPG). $\beta$-gal III presented $\beta$-fucosidase and $\alpha$-arabinosidase activities, but there was practically no $\beta$-xylosidase activity and did not present capacity to hydrolyze PNP- $\beta$-D-glucopyranoside, PNP- $\alpha$-D-mannopyranoside and PNP- $\alpha$-L-fucopyranoside substrates.

Table 3. Enzymatic activity of $\beta$-gall, $\beta$-gal Il and $\beta$-gal III of cowpea seedling stems [Vigna unguiculata (L.) Walp.] cv. Pitiúbain differentp-nitrophenyl glycoside substrates.

\begin{tabular}{|c|c|c|c|}
\hline \multicolumn{4}{|c|}{ [ $\beta$-galactosidase activity (UA.h-1)] / [\% of control ( $\beta$-PNPG)] } \\
\hline $\begin{array}{r}\text { Substrate } \\
\end{array}$ & $\beta$-gal I & $\beta$-gal II & $\beta$-gal III \\
\hline PNP- $\beta$-D-alactopyranoside & $164.8(100 \%)$ & $2,240.0(100 \%)$ & $595.9(100 \%)$ \\
\hline PNP- $\beta$-D-xylopyranoside & $83.2(50.5 \%)$ & $0(0 \%)$ & $12.8(2.1 \%)$ \\
\hline PNP- $\beta$-D-fucopyranoside & $155.2(94.2 \%)$ & $476.8(21.2 \%)$ & $76.8(12.8 \%)$ \\
\hline PNP- $\beta$-D-glucopyranoside & $108.8(66.0 \%)$ & $0(0 \%)$ & $0(0 \%)$ \\
\hline PNP- $\alpha$-L-rabinopyranoside & $110.4(66.9 \%)$ & $230.4(10.2 \%)$ & $57.6(9.6 \%)$ \\
\hline PNP- $\alpha$-D-annopyranoside & $144.0(87.3 \%)$ & $0(0 \%)$ & $0(0 \%)$ \\
\hline PNP- $\alpha$-D-alactopyranoside & $112.0(67.9 \%)$ & $0(0 \%)$ & $192.0(32.2 \%)$ \\
\hline PNP- $\alpha$-L-fucopyranoside & $100.8(61.1 \%)$ & $0(0 \%)$ & $0(0 \%)$ \\
\hline
\end{tabular}




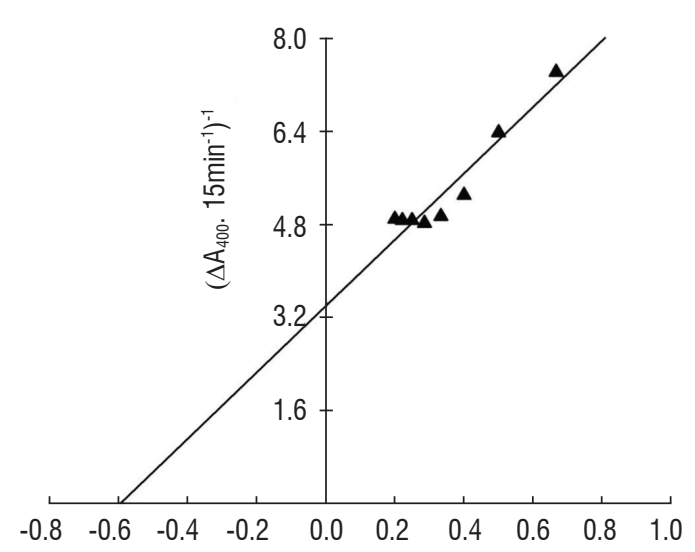

[Substrate $^{-1}\left(\mathrm{mM}^{-1}\right)$

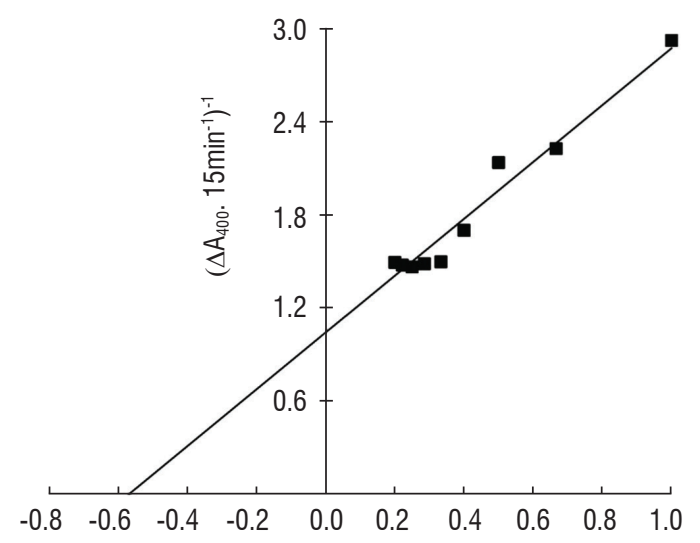

[Substrate $]^{-1}\left(\mathrm{mM}^{-1}\right)$

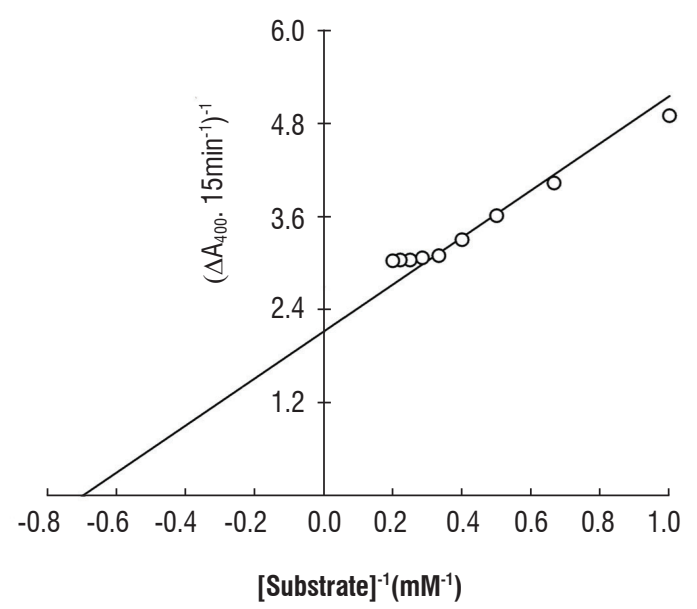

Figure 6. Double-reciprocal plots (Lineweaver-Burk) for $\beta$-Gal I (A), $\beta$-Gal II (B) and $\beta$-Gal III (C) of cowpea seedling stems [Vigna unguiculata (L.) Walp.] cv. Pitiúba obtained of enzymatic activity as a function of crescent concentrations of the $\beta$-PNPG substrate.

\section{DISCUSSION}

Plant $\beta$-galactosidases are often basic proteins exhibiting pl greater than 7.0 (Simos et al., 1989; Enéas-Filho et al., 2000; Li et al., 2001; Balasubraniam et al., 2005). It seems to be the case of the $\beta$-galactosidases here purified and characterized, which also have the same optimal pH (4.0). Therefore, an electrophoresis methodology in acid gel specific for basic proteins (Goldenberg, 1997) was adopted in the present study. A similar electrophoretic profile (Figure 2) was previously observed in Phaseolus vulgaris (Biswas et al., 2003).

Molecular mass differences found among the $\beta$-galactosidases analyzed (Figure 3 ) could reflect the distinct nature of the three enzymes - two cytosolic isoforms ( $\beta$-gal I and II) and another one associated with the cell wall ( $\beta$-gal III). In fact, different molecular masses have been described for $\beta$-galactosidases previously purified from different plant tissues (e.g., Li et al., 2001; Biswas et al., 2003; Balasubraniam et al., 2005; Alcântara et al. 2006).

The optimal pH presented by $\beta$-gal I, II and III (Figure 4A) is common to a broad variety of plant species (Enéas-Filho et al. , 2000 and 2001; Li et al., 2001; Chilaka et al., 2002; Biswas et al., 2003; Alcântara et al., 2006). Furthermore, the optimal temperature range observed in Figure $4 \mathrm{~B}$ is also similar to that found in other $\beta$-galactosidases purified from plants (Enéas-Filho et al., 2000 and 2001; Li et al., 2001; Chilaka et al., 2002). Despite the similarities among $\beta$-gal I, II and III enzymes regarding the thermal stability, $\beta$-gal II was the most sensitive at higher temperatures (Figure 4C). Previous studies on thermal stability of $\beta$-galactosidases from Vigna radiata seeds (Kundu et al., 1990) and Vigna unguiculta cotyledons (Enéas-Filho et al., 2000) reported quite similar results, with minor or no inactivation of the enzymes pretreated at $50^{\circ} \mathrm{C}$, but exhibiting considerable inactivation above $55^{\circ} \mathrm{C}$. Slightly different results were reported by Sekimata et al. (1989) for $\beta$-galactosidases from radish seeds, which were already completely inactivated at $55^{\circ} \mathrm{C}$.

According to Daniel et al. (1996), biphasic thermal inactivation curves like that observed in Figure 5 , can reflect the ability of the enzyme to exist in more than one stable 
conformational state. Since $\beta$-gal III was almost completely inactivated upon pretreatment at $60^{\circ} \mathrm{C}$ for 40 minutes, and $\beta$-gal I and II enzymes resisted until 80 minutes at the same pretreatment, it is possible that the $\beta$-galactosidase derived from cell wall ( $\beta$-gal III) is more sensitive to thermal inactivation than the cytosolic counterparts ( $\beta$-gal I and II).

Figure 5 explores the thermal inactivation of $\beta$-gal I, II and III in the presence of glucose or galactose and the data suggest the involvement of changes in the active site of the enzymes, since their activities were preserved even at high temperatures due to the protection induced by glucose and galactose. These sugars probably connect to the active site changing the enzyme conformation and making them more resistant to high temperatures (Chilaka et al., 2002). The data reported by Chilaka et al. (2002) for Kestingella geocarpa enzymes are similar to those found in Figure 5, the thermal inactivation curves as a function of time were also biphasic, glucose and galactose also protected the K. geocarpa $\beta$-galactosidases, with $100 \%$ protection in the case of galactose at a concentration of $100 \mathrm{mM}$.

The $\beta$-gal I, II and III also exhibited different inhibitory patterns for the different sugars tested (Table 2). Similar to the present results, the activities of Vigna radiata cotyledon $\beta$-galactosidases (Li et al., 2001) were also strongly inhibited in the presence of galactose (about 70\%) and 28\% in the presence of lactose. Arabinose and fucose practically did not inhibit enzyme activity in $V$. radiata (Li et al., 2001). This strong inhibition pattern for galactose (especially) and lactose was also reported in the study by Chilaka et al. (2002) with K. geocarpa cotyledonal $\beta$-galactosidases. The $\beta$-galactosidase inhibition was also found to be higher with galactose and lesser with glucose in Hymenaea courbaril cotyledons (Alcântara et al., 2006). Different sugars structurally related to galactose tend to act as inhibitors binding to the active site acting as competitive inhibitors or even in other enzyme regions, as uncompetitive and noncompetitive inhibitors (Nelson and Cox, 2000).

Most kinetic studies on $\beta$-galactosidases use $\beta$-PNPG as substrate (e.g., Biswas et al., 2003; Balasubraniam et al., 2005; Alcântara et al., 2006). Enzymatic kinetics of the enzymes purified in this study indicate that $\beta$-gal III have a slightly higher affinity for $\beta$-PNPG than for $\beta$-gal I and II (Figure 6).
The study of $\beta$-gal I, II and III activities in relation to their capacities to hydrolyze different substrates (Table 3) revealed differences between the two cytosolic $\beta$-galactosidases ( $\beta$-gal I and II) and among them and the cell wall $\beta$-galactosidase ( $\beta$-gal III), which also may suggest different functions. As observed in this study, some authors also observed that purified $\beta$-galactosidases from different plant species also presented the capacity to hydrolyze different $p$-nitrophenyl glycosides, besides $\beta$-PNPG (Ali et al., 1995; Li et al., 2001; Alcântara et al., 2006). Specificity studies of cytosolic $\beta$-galactosidases isoforms of Mangifera indica fruits were performed by Ali et al. (1995). In this study, the isoforms were unable to hydrolyze any $p$-nitrophenyl glycoside tested, showing that the enzymatic preparation was totally free of $\beta$-glucosidase and $\alpha$-manosidase activity, agreeing with the results observed with $\beta$-gal II and $\beta$-gal III enzymes (Table 3 ). Besides the absence of these activities, $M$. indica $\beta$-galactosidases also did not present $\alpha$-arabinosidase activity. Like the $\beta$-gal I, $\beta$-gal II and $\beta$-gal III (Table 3 ), different $\beta$-galactosidase isoforms associated with the cell wall isolated from Vigna radiata cotyledons also revealed different behavior regarding their capacity to degrade different substrates (Li et al., 2001). Alcântara et al. (2006) observed there was no $\beta$-manosidase and $\beta$-xylosidase activity in the $\beta$-galactosidases present in the cell wall of Hymenaea courbaril cotyledons, similar to what was observed for $\beta$-gal II and III (Table 3). Considering that $\beta$-galactosidases can act on the mobilization of cell wall constituents during plant germination and growth, the analysis of specificity these enzymes in relation to different substrates is crucial for understanding the possible physiological roles accomplished by these enzymes in this plant species.

\section{CONCLUSION}

The $\beta$-gal I, $\beta$-gal II and $\beta$-gal III enzymes purified from Vigna unguiculata have very similar kinetic behaviors, however they also exhibit clear differences, such as in molecular mass, thermal stability and substrate hydrolysis specificity, indicating that the cytosolic enzymes $\beta$-gal I and II and the cell wall derived $\beta$-gal III can play different functions in the stem development of cowpea seedlings. 
Acknowledgements: This work was supported by the grants and scholarships from the Coordenação de Aperfeiçoamento de Pessoal de Nível Superior (CAPES), INCTSal/CNPq, Conselho Nacional de Desenvolvimento Científico e Tecnológico (CNPq) and Fundação Cearense de Apoio ao Desenvolvimento Científico e Tecnológico (FUNCAP). We thank Professor Emeritus José Tarquínio Prisco for his constant guidance in carrying out this study.

\section{REFERENCES}

Alcântara PHN, Martim L, Silva C0, Dietrich SMC, Buckeridge MS (2006) Purification of a $\beta$-galactosidase from cotyledons of Hymenaea courbaril $\mathrm{L}$. (Leguminosae). Enzyme properties and biological function. Plant Physiol Biochem. 44:619-627.

Ali ZM, Armugam S., Lazan H (1995) $\beta$-galactosidase and its significance in ripening mango fruit. Phytochem. 38:1109-1114.

Balasubranian S, Lee HC, Lazan H, Othman R, Ali ZM (2005) Purification and properties of a $\beta$-galactosidase from carambola fruit with significant activity towards cell wall polysaccharides. Phytochem. 66:153-163.

Biswas S, Kayastha AM, Seckler R (2003) Purification and characterization of a thermostable $\beta$-galactosidase from kidney beans (Phaseolus vulgaris L.) cv. PDR14. J. Plant Physiol. 160:327-337.

Biswas TK (1987) Characterization of $\beta$-galactosidases from the germinating seeds of Vigna sinensis. Phytochem. 26: 359-364.

Blum H, Beier H, Gross HJ (1987). Improved silver staining of plant proteins, RNA and DNA in polyacrylamide gels. Electrophoresis. 8:93-99.

Chilaka FC, Okeke C, Adaikpoh E (2002) Ligand-induced thermal stability in $\beta$-galactosidase from the seeds of the black bean, Kestingeilla geocarpa. Process Biochem. 38:143-149.

Daniel RM, Dines M, Petach HH (1996) The denaturation and degradation of stable enzymes at high temperatures. Biochem. J. 317:1-11.

Enéas Filho J, Barbosa GKC, Sudério FB, Prisco JT, Gomes Filho E (2001) Isolation and partial purification of $\beta$-galactosidases from cotyledons of two cowpea cultivars. Rev. Bras. Fisiol. Veg. 13:251-261.

Enéas Filho J, Oliveira Neto OB, Prisco JT, Gomes Filho E, Nogueira CM (1995) Effects of salinity in vivo and in vitro on cotyledonary galactosidases from Vigna unguiculata (L.) Walp. during germination and seedling establishment. Rev. Bras. Fis. Veg. 7:135-142.

Enéas Filho J, Sudério FB, Gomes Filho E, Prisco JT (2000) Multiple forms of cotyledonary $\beta$-galactosidases from Vigna unguiculata quiescents seeds. Rev. Bras. Bot. 23:69-76.

Ferreira CM (2001) Comercialização de feijão no Brasil. Piracicaba, Universidade de São Paulo - Escola Superior de Agricultura "Luiz de Queiroz". Dissertação de Mestrado em Ciências. 145p.

Freire Filho FR (1988) Origem, evolução e domesticação do caupi. In: Araújo JPP, Watt EE (eds). 0 caupi no Brasil, pp. 27-46. Brasília: IIta/EMBRAPA.

Fry SC (2004) Primary cell wall metabolism: tracking the careers of wall polymers in living plant cells, New Phytol. 161:641-675.
Goldenberg DP (1997) Analysis of protein conformation by gel electroforesis. In: Creighton TE (ed), Protein structure: A practical approach, pp195. Oxford University Press Inc., New York.

Gómez LD, Casano LM, Braga MR, Buckeridge MS (1995) Changes in extracellular $\beta$-galactosidase and protease activities during bean hypocotyls growth. Rev. Bras. Fis. Veg. 7:1-6.

Granjeiro PA, Ferreira CV, Cavagis ADM, Granjeiro JM, Ayoama H (2003) Essential sulfhydryl groups in the active site of castor bean (Ricinus communis) seed acid phosphatase. Plant Sci, 164: 629-633.

Kanfer JN, Petrovich R, Mumford RA (1973) Purification of $\alpha$ - e $\beta$-galactosidases by affinity chromatography. Anal. Biochem. 55:301305.

Konno H, Tsumuki H (1993) Purification of a $\beta$-galactosidase from rice shoots and its involvement in hidrolysis of the natural substrate in cell walls. Physiol. Plant. 89:40-47.

Kundu RK, De Kundu P, Banerjee AC (1990) Multiple forms of $\beta$-galactosidase from the germinating seeds of Vigna radiata. Phytochem. 29:2079-2082.

Li SC, Han JW, Chen KC, Chen CS (2001) Purification and characterization of isoforms of $\beta$-galactosidases in mung bean seedlings. Phytochem. $57: 349-359$

Matthews BW (2005) The structure of $E$. coli $\beta$-galactosidase. C. R. Biologies. 328:549-556.

Mcllwaine TC (1921) A buffer solution foil colorimetric comparison. J. Biol. Chem. 49:185-186.

Minic Z, Jouanin L (2006) Plant glycoside hydrolases involved in cell wall polysaccharide degradation. Plant Physiol. Biochem. 44:435-449.

Molina L, Constantinescu F, Michel L, Reimmann C, Duffy B, Défago G (2003) Degradation of pathogen quorum-sensing molecules by soil bacteria: a preventive and curative biological control mechanism. FEMS Microbiol. Ecol..45:71-81.

Nelson DL, Cox MM (2004) Lehninger Principles of Biochemistry. 4th edition. Worth

Pérez Almeida I, Carpita, NC (2006) Las $\beta$-galactosidasas y la dinâmica de la pared celular. Interciencia. 31:476-482.

Prisco JT (1980) Alguns aspectos da fisiologia do "stress" salino. Rev. Bras. Bot. 3:85-94

Sawicka T, Kacperska A (1995) Soluble and cell wall-associated $\beta$-galactosidases from cold-grown winter rape (Brassica napus L., var. oleifera L.). J. Plant Phisiol. 145:357-362.

Seara J, Nicolás G, Labrador E (1988) Autolysis of the cell wall. Its possible role in endogenous and IAA-induced growth in epicotyls of Cicer arietnum. Physiol Plantarum. 72:762-774.

Sekimata M, Ogura K, Tsumaraya Y, Hashimoto Y, Yamamoto S (1989) A $\beta$-galactosidase from radish (Raphanus sativus L.) seeds. Plant Physiol. 90:567-574.

Simos G, Georgatsos JG (1988) Lactose-hidrolizing $\beta$-glycosidases of barley meal. Biochem. Biophys. Acta. 967:17-24.

Simos G, Giannkouros T, Georgatsos JG (1989) Plant $\beta$-galactosidases: purification by affinity chromattography and properties. Phytochem. 28:2587-2592.

Singh BB, Ajeigbe HA, Tarawali SA, Fernandez Rivera S, Abubakar M (2003) Improving the production and utilization of cowpea as food and fodder. Field Crops Res. 84:169-177. 